\title{
The Effect of Benomyl Treatments on Ginsenosides and Arbuscular Mycorrhizal Symbiosis in Roots of Panax ginseng
}

\author{
Ju-Kyeong Eo ${ }^{1}$ and Ahn-Heum Eom ${ }^{2}$ ** \\ ${ }^{1}$ Department of Forest Sciences, Seoul National University, Seoul 151-921, Korea \\ ${ }^{2}$ Department of Biology Education, Korea National University of Education, Chungbuk 363-791, Korea \\ (Received September 11, 2009; Revised December 15, 2009; Accepted December 15, 2009)
}

\begin{abstract}
The effects of benomyl treatment on ginsenoside and arbuscular mycorrhizal (AM) symbiosis in the roots of Panax ginseng that were collected from two sites in Korea were investigated. The ginseng roots that were treated with benomyl showed different species compositions of AM fungi colonizing the ginseng roots, compared to untreated roots. In the analysis of ginsenoside, Rc was significantly higher in benomyl untreated roots than in benomyl treated roots. The results suggest that AM fungal species composition and ginsenosides in ginseng root could be influenced by the benomyl treatment.
\end{abstract}

Key Words : Panax ginseng, Glomus sinuosum, Paraglomus occultum, benomyl, ginsenoside

\section{INTRODUCTION}

Ginseng (Panax ginseng C. A. Meyer) is a slow-growing perennial herb with thick roots and palmate leaves. ${ }^{1)}$ Its inflorescence is umbel, and mature fruits are reddish or yellowish. The herb belongs to the genus Panax and family Araliaceae. This genus includes about 15 ginseng species, most of which are used as medicines. ${ }^{2-4)}$ Ginseng's medicinal effects are attributable to ginsenosides, which are about 40 kinds of saponin in the root that were analyzed their chemical structure. ${ }^{5)}$ Ginsenosides constituent only $3-6 \%$ of the total ginseng weight but have many positive effects on the human body. ${ }^{6}$ ) The production and content of ginsenosides are correlated to the herb's genetic set and environmental conditions, including soil chemical compounds, climatic conditions, and the relationship with different organisms. Ginsenosides are commonly thought to be secreted for self-protection, to maintain homeostasis against attack by other organisms. ${ }^{7)}$

The arbuscular mycorrhizal fungi (AMF) belonging to Glomeromycota $^{8)}$ have a symbiotic relationship with most terrestrial plants: the plants provide the carbon source to the AMF and the AMF supply inorganic materials to the plants. AMF increased growth and survivorship of $P$. quinquefolius. ${ }^{9)}$ Domey and Bermann ${ }^{10)}$ showed that a

\footnotetext{
* Corresponding author. E-mail: eomah@knue.ac.kr Phone: +82-43-230-3767, Fax: +82-43-238-9511
}

different AMF - Glomus intraradices and G. albium influenced growth and nutrient content of ginseng differently. Moreover, Fourneir et al. ${ }^{11)}$ showed that inoculation AMF influenced not only growth and survivorship but also root ginsenoside of $P$. quinquefolius. However, only a few studies have been conducted on the relationship of Korean ginseng with AMF in Korea. Most of them focused on morphological characterization and identification of the AMF by analysis of roots and soils in cultivated fields ${ }^{12,13)}$ or natural fields of ginseng. ${ }^{14)}$ In the present study, we added benomyl, a permeable fungicide, to AMF colonized two-year-old ginseng planted pots to suppress mycorrhizal symbiosis ${ }^{15,16)}$ and compared those with untreated control ginseng roots with the aim of determining the effects of benomyl treatment of ginseng roots on species composition of the AMF colonizing the roots using molecular analysis and also on the ginsenoside content of the roots.

\section{MATERIALS AND METHODS}

\section{Samples}

Thirty roots of 2-year-old ginseng were obtained from the same cultivated field at Geumsan, Chungnam province, Korea. The roots were divided into two groups and grown in sterile-soil pots under greenhouse conditions for 6 months. One group was left untreated for use as a control, and the other group was treated with $200 \mathrm{ml}$ of $1 \%$ 
benomyl (Dongbu Fine Chemicals Co., Korea) once a week. Quarter-strength Hoagland's solution $\left(2.8 \mathrm{~g} \mathrm{H}_{3} \mathrm{BO}_{3}, 3.4 \mathrm{~g}\right.$ $\mathrm{MnSO}_{4} \cdot \mathrm{H}_{2} \mathrm{O}, 0.1 \mathrm{~g} \mathrm{CuSO}_{4} \cdot 5 \mathrm{H}_{2} \mathrm{O}, 16.22 \mathrm{~g} \mathrm{ZnSO}_{4} \cdot 7 \mathrm{H}_{2} \mathrm{O}$, $0.1 \mathrm{~g}\left(\mathrm{NH}_{4}\right)_{6} \mathrm{Mo}_{7} \mathrm{O}_{24} \cdot 4 \mathrm{H}_{2} \mathrm{O}, 5 \mathrm{ml} \mathrm{H} \mathrm{SO}_{4}, 6.72 \mathrm{~g} \mathrm{Na}_{2} \mathrm{EDTA}$, $\left.5.58 \mathrm{~g} \mathrm{FeSO}_{4}, 0.94 \mathrm{~g} \mathrm{Ca} \mathrm{NO}_{3}\right)_{2} \cdot 4 \mathrm{H}_{2} \mathrm{O}, 0.52 \mathrm{~g} \mathrm{MgSO}_{4} \cdot 7 \mathrm{H}_{2} \mathrm{O}$, $0.66 \mathrm{~g} \mathrm{KNO}_{3}$, and $\left.0.06 \mathrm{~g} \mathrm{HN}_{4} \mathrm{H}_{2} \mathrm{PO}_{4}\right)$ was added to both groups weekly.

\section{DNA sequence analyses of AMF}

DNA extraction, nested PCR, cloning, PCR-RFLP and sequencing were performed. ${ }^{17)}$ Template DNA of AMF was prepared by the CTAB method, and then, the nested PCR was used to amplify the $18 \mathrm{~S}$ rDNA region. ${ }^{18)}$ The PCR product was purified for cloning, performed by using the pGEM-T Easy Vector System (Promega Co., USA). Restriction enzymes Hinfl, Asu21 (Bioneer Co., Korea), and $H s p$ 92II (Promega Co., USA) were used for PCR-RFLP. Then, these fragments pattern were detected and colonies were divided into each group and representative colony was selected in each group. Its colony was incubated in LB/ampicillin medium and in order to analysis of AMF sequences plasmids were extracted in each incubated cells. The nucleotide sequence of one clone from each RFLP type was determined using an automatic sequencer (ABI Prism; Applied Biosystems, USA) in Eugenetech Co. (Korea). DNA sequence analyses were performed with BLAST, available at the National Center for Biotechnology Information (NCBI) Web site (http:// blast.ncbi.nlm.nih.gov). The relative positions of the sequences were examined in a phylogenetic tree using MEGA 4.0. ${ }^{19}$

\section{Ginsenoside analysis}

Dried ginseng roots $(1 \mathrm{~g})$ were homogenized. ginseng powders were extracted in a rotary evaporator with $50 \mathrm{ml}$ of $80 \% \mathrm{MeOH}$. Extracting was conducted twice and filtered through filter paper. In ginseng extract, methanol was evaporated and the residuum was dissolved in $50 \mathrm{ml}$ distilled water. After $50 \mathrm{ml}$ water solution and ethyl ether $(50 \mathrm{ml})$ put in separator funnel, discarded ether layer. The process conducted twice. In aqueous layer, saponin was extracted 3 times using spor-butanol that first sporbutanol volume is $50 \mathrm{ml}$ and second, third volume is 40 $\mathrm{ml}$, and aqueous layer was discarded. The spor-butanol layer was washed with distilled water twice and evaporated in vacuum at $50^{\circ} \mathrm{C}^{20)}$. Finally, concentrate was dissolve in methanol of 5 times of methanol and filtrated with $0.45 \mu \mathrm{l}$ PTEF membrane filter. The contents of saponin was analyzed by HPLC (Waters 2690 separation module; Waters 996 photodiode array detector; Waters millennium 2010 chromatography manager) on the Altec Platinum C18 column (particle size. $1.5 \mu \mathrm{m}, 33 \times 7 \mathrm{~mm}$ ), with water and acetonitrile. The rate of water and acetonitrile for first $10 \mathrm{~min}$ and late $15 \mathrm{~min}$ were $75: 25$ and $63: 37$, respectively. Flow rate of the mobile phase was 1.0 $\mathrm{ml} \mathrm{min}{ }^{-1}$ and monitoring of ginsenoside was $203 \mathrm{~nm}$. The standard ginsenosides purchase Wako Pure chemical industries, Ltd.(Japan).

\section{RESULTS AND DISCUSSION}

\section{Identification of AMF}

On the basis of RFLP patterns of AMF, colonies were divided into 11 groups, and 18s rDNA of one representative colony was sequenced from each group: colony 011 , 012, 014, 015, 016, 017, 019, 021, 023 024, 031. The sequences were identified through BLAST as Paraglomus sp. and Glomus spp. (Table 1), but other colonies were identified as a $P$. ginseng. Detection of Paraglomus colonization in roots by using classical staining methods is difficult because of weak staining with trypan blue or other traditional acidic stains . Furthermore, it is not possible to identify hyphae of AMF in stained roots into species level; hence, molecular techniques should be used to identify the fungal community colonizing the roots. The spores of Paraglomus and Glomus spp. have similar morphological characteristics, which makes distinguishing between the species difficult. ${ }^{21,22)}$

The AMF colonizing the ginseng roots in this study are similar to those observed by Eom et al. ${ }^{17)}$ even though

Table 1. The result of BLAST for sequences from benomyl treated and control roots of Panax ginseng

\begin{tabular}{ccccc}
\hline \hline Treatment & Colony ID & The closest species & Accession No. & Identity \\
\hline \multirow{3}{*}{ Control } & 011 & Glomus sinuosum & AJ133706.1 & $714 / 737(96 \%)$ \\
& 016 & Glomus sinuosum & AJ133706.1 & $689 / 730(94 \%)$ \\
& 017 & Glomus sinuosum & AJ133706.1 & $584 / 603(96 \%)$ \\
Benomyl & 019 & Glomus sinuosum & AJ133706.1 & $479 / 516(92 \%)$ \\
& 021 & Paraglomus occultum & AM295493.1 & $556 / 563(98 \%)$ \\
& 024 & Paraglomus occultum & AM295493.1 & $650 / 677(96 \%)$ \\
\hline
\end{tabular}


the ginseng-cultivated fields differ. Sequence analyses of the roots from both treatment groups showed the presence of 4 species from 2 genera of AMF (Fig. 1): 2 Glomus sp. were detected in the control group and 1 species each of Glomus and Paraglomus were found in the benomyltreated roots. Eom et al. ${ }^{17)}$ showed the presence of Paraglomus spp. in field-cultivated ginseng roots, suggesting

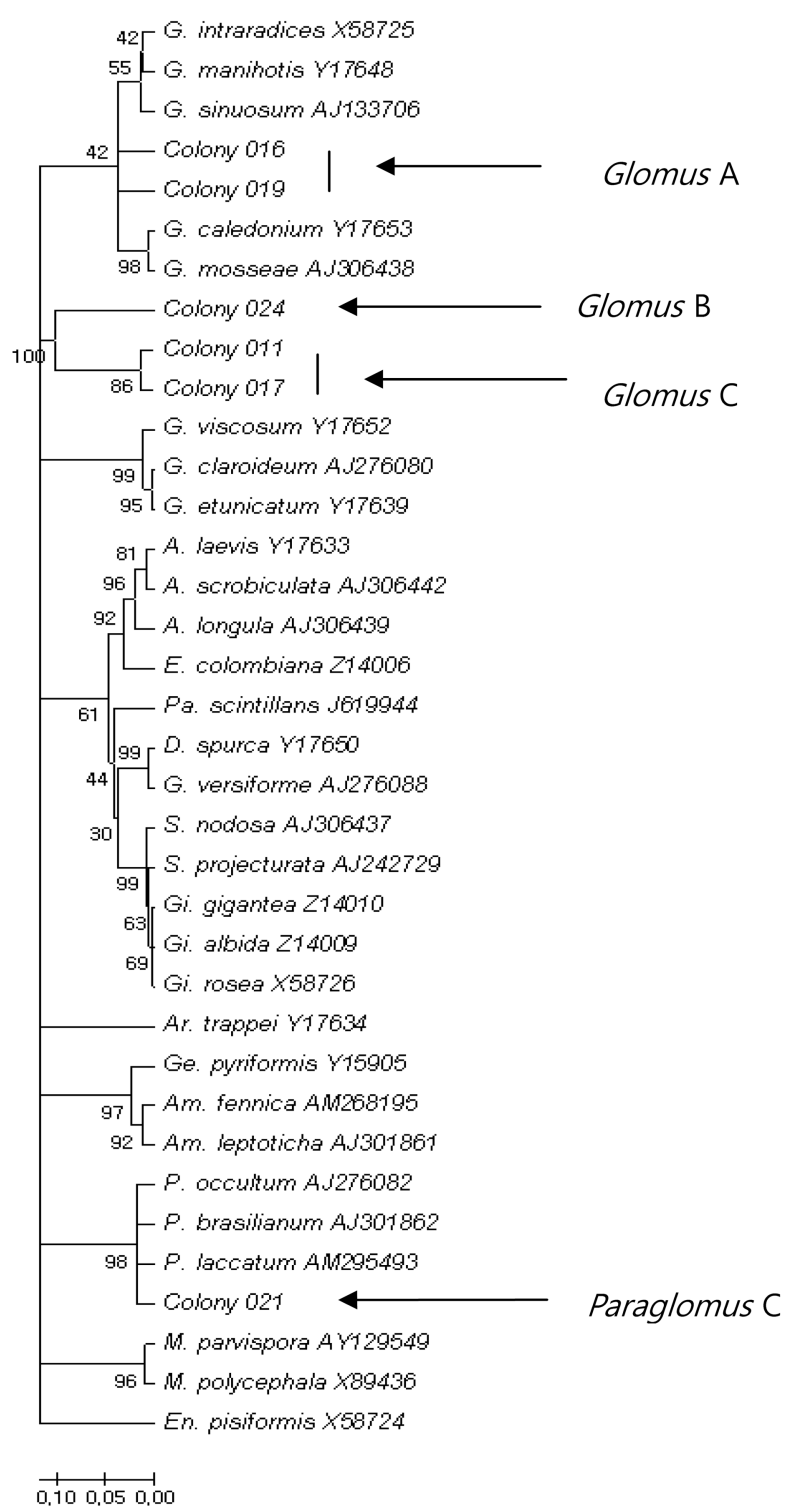

Fig. 1. Neighbour-joining tree of partial sequences of 18s rDNA from ginseng roots. Colonies 011, 016, 017 and 019 were from control roots and colonies 021 and 024 were from benomyl treated roots. The tree consists of 30 AMF species sequences with 6 sequences from this study. Bootstrap values (1,000 replicate) are shown on each clade and Endogone pisiformis, Motierella parvispora and $M$. polycephala were used as outgroup. that benomyl influences the colonization of G. sinuosum in ginseng roots. The present study result shows the different effect of benomyl treatment on the colonization of Glomus and Paraglomus spp: the colonization of a Glomus sp. in the roots was suppressed but not that of Paraglomus spp.

\section{Ginsenoside analysis}

It has been reported about 40 ginsenosides in the root from $P$. ginseng, and 7 of which, namely, $\mathrm{Rb}_{1}, \mathrm{Rb}_{2}, \mathrm{Rc}$, $\mathrm{Rd}, \mathrm{Re}, \mathrm{Rf}$, and $\mathrm{Rg}_{1}$, are reported as important components. ${ }^{5,23)}$ In this study, these 6 ginsenosides in the ginseng roots were analyzed after benomyl treatment (Fig. 2). There was no statistically significant difference in the ginsenoside content between the groups except for Rc. The control group showed a significantly higher amount of Rc than the benomyl-treated roots $(\mathrm{p}<0.05)$. Total and other ginsenosides, Rb1, Rd, Rf and Rg1 showed lower in benomyl treated roots and than in the control roots, though the difference was not statistically significant. The results in this study showed that root ginsenoside content was decreased after suppression of AMF colonization in root by benomyl treatments increased, suggesting that AMF colonization would increase ginsenoside contents. Results are concordant with a previous study ${ }^{11)}$ showed that ginsenoside content in the root increase when American ginseng are grown with AMF inoculated soil. Ginsenosides have potent anti-fungal activities and function as preformed chemical defense against fungal infection. Furthermore, there has been many reports that AMF colonization induce accumulation of various kinds of secondary

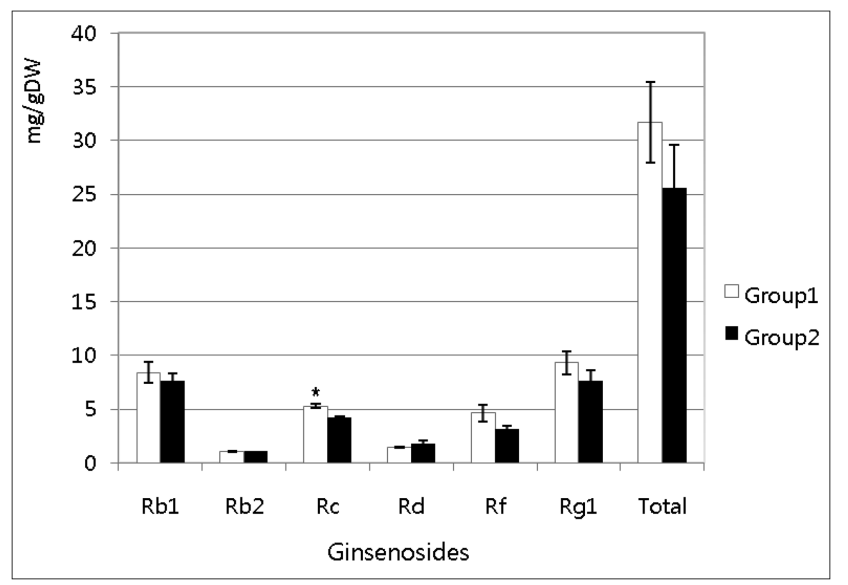

Fig. 2. Ginsensides contents of control ginseng roots (group 1) and benomyl treated roots (group 2). Asterisk indicate significant difference between groups at $\mathrm{P}<0.05$. DW indicates dry weight of root samples. 
metabolites in host plants ${ }^{24)}$ and protect host from pathogens. ${ }^{25)}$ Han et $a l .{ }^{26)}$ reported that AM inoculation increase resistance of ginseng to pathogenic fungi, though they did not analyze ginsenosides in the roots. It would be speculated that mycorrhizal colonization stimulates accumulation of secondary metabolite including ginsenosides to protect plant from other soil pathogens.

In summary, our results are concordant with a previous study that ginsenoside content in the root increases with AMF colonization. Also, this study showed that Paraglomus sp. was found in the benomyl-treated roots and Glomus spp. were found in both the untreated and benomyltreated roots, suggesting that the fungicide affects the species composition of the AMF colonizing ginseng roots and the mycorrhizal root colonization rate.

\section{REFEENCES}

1. Brummitt R, Powell C. Authors of plant names. Royal Botanic Gardens, Kew (1992)

2. Wu Z, Raven P. Flora of China. Missouri Botanical Garden Press, St. Louis, USA (1999)

3. Park C. The Genera of vascular plants of Korea. Academy Publishing, Seoul (2005)

4. Lee Y. Flora of Korea. Kyo-Hak Publishing Company, Seoul (2004)

5. Kim D. Reviews in Ginseng Research (I). The Korea Society of Ginseng, Seoul (2007)

6. Wang H, Actor J, Indrigo J, Olsen M, Dasgupta A. Asian and Siberian ginseng as a potential modulator of immune function: an in vitro cytokine study using mouse macrophages. Clinica Chimica Acta 327: 123-128 (2003)

7. Lee M, Park H, Lee C. Effect of growth conditions on saponin content and ginsenoside pattern of Panax ginseng. Proc Korea-Japan Panax ginseng symposium 11: 89-107 (1987)

8. Schußler A, Schwarzott D, Walker C. A new fungal phylum, the Glomeromycota: phylogeny and evolution. Mycol Res. 105: 1414-1421 (2001)

9. Li T. Effect of vesicular-arbuscular mycorrhizae on the growth of American Ginseng. Korean J Ginseng Sci. 19: 73-76 (1995)

10. Domey S, Leinhos V, Dautz S, Bergmann H. Influence of vesicular-arbuscular mycorrhiza infection on protein content and protein patterns in Ginseng (Panax ginseng C. A. Meyer). Angewandte Botanik 72: 107-112 (1998)

11. Fournier AR, Khanizadeh S, Gauthier L, Gosselin A, Dorais M. Effect of two Glomus species inoculation on survival, photosynthetic capacity, growth, morphology and root gensenoside content of $P$. quinquefolius L. J Ginseng Res. 27: 178-
182 (2003)

12. Song S, Min E, Chang G. Comparisons of the major element contents for the Korean ginseng from various soils of Keumsan. J Ginseng Res. 32: 194-209 (2008)

13. Sohn B, Jin S, Lee D. Distribution of arbuscular mycorrhizal Fungi(AMF) at ginseng cultivated fields in Jeonnam province. Kor J Soil Science Fertil. 41: 214-222 (2008)

14. Lee K, Lee K, Park H, Budi S. The rate and morphology of mycorrhizal infection in the wild ginseng (Panax ginseng $\mathrm{C}$. A. Mey.) collected from various locations in Korea. J Ginseng Res. 30: 206-611 (2006)

15. Hale K, Sanders F. Effects of benomyl on vesicular-arbuscular mycorrhizal infection of red clover (Trifolium pratense L.) and consequences for phosphorus inflow. J Plant Nutrition 5: 1355-1367 (1982)

16. Fitter A, Nichols R. The use of benomyl to control infection by vesicular-arbuscular mycorrhizal fungi. New Phytol. 110: 201-206 (1988)

17. Eom A, Eo J, Kim D, Jeong H. Identification of arbuscular mycorrhizal fungi colonizaing Panax ginseng using $18 \mathrm{~S}$ rDNA sequence. J Korean Sci Appl Biol Chem. 47: 182-186 (2004)

18. Ausubel F, Brent R, Kingston R, Moore D, Seidman J, Smith J, Struhl K. Short protocols in molecular biology. John Wiley \& Sons, New York (1999)

19. Tamura K, Dudley J, Nei M, S K. MEGA4: Molecular evolutionary genetics analysis (MEGA) software version 4.0. Mol Biol Evol. 24: 1596-1599 (2007)

20. Kim C, Kim M, Choi G, Shon H, Ko S, Kim S, Ui J, Heo J. Analytical methods of Ginseng components. Korea Ginseng \& Tobacco Research Institute, Deajeon (1991)

21. Walker C. Species in the Endogonaceae: a new species (Glomus occultum) and a new combination (Glomus geosporum). Mycotaxon 15: 49-61 (1982)

22. Spain J, de Miranda J. Glomus brasilianum: An ornamented species in the Glomaceae. Mycotaxon 60: 137-142 (1996)

23. Hong HD. Qualitative and quantitative analysis of ginsenoside. Korean J Crop Science 49: 146-154 (2004)

24. Peipp H, Maier W, Schmidt J, Wray V, Strack D. Arbuscular mycorrhizal fungus-induced changes in the accumulation of secondary compounds in barley roots. Phytochemistry 44: 581-587 (1997)

25. Smith SE, Read DJ. Mycorrhizal Symbiosis. 3rd ed. Academic Press, London (2008)

26. Han KD, Lee SS, Kim SH, Lee MW. Effects of beneficial microorganisms and mycorrhizal fungus colonized rhizoplane on the suppression of root rot pathogen, Fusarium solani. Korean J Mycol. 24: 38-48 (1996) 